4. Кінг П. Стратегії і тактики спілкування, або Як знайти спільну мову з кожним. Книголав, 2017. 128 с.

5. Friedrichs J., Schwinges U. Das journalistische Interview. Wiesbaden : VS Verlag, 2005. 323 S.

6. Haller M. Das Interview. 5. Aufl. Konstanz, München : UVK, 2013. 346 S.

7. Häusermann, J., Käppeli, H. Rhetorik für Radio und Fernsehen. Aarau/Frankfurt am Main : Sauerländer, 1994. 182 S.

UDC 81'253+372.461+81'282

DOI https://doi.org/10.32782/tps2663-4880/2019.11-2.12

\title{
COMPARATIVE ANALYSIS OF THE CHINESE AND ENGLISH INTERNET-LANGUAGE
}

$$
\text { ЗІСТАВНИЙ АНАЛІЗ КИТАЙСЬКОЇ ТА АНГЛІЙСЬКОЇ МОВИ ІНТЕРНЕТУ }
$$

\author{
Oskina N.O., \\ orcid.org/0000-0001-5764-2600 \\ Candidate of Pedagogical Sciences, \\ Associate Professor of the Department \\ of Western and Oriental Languages and Methods of their Teaching \\ South Ukrainian National Pedagogical University named after K.D. Ushinsky
}

The presented article is aimed at elaborating the problem of specific features of the Internet language in the contrasted typologically not closely related languages: English and Chinese. On the basis of the analysis of the corpus of slang words and neologisms selected from the investigated Internet-chats (Internet slang glossaries) in Chinese and English there has been concluded that the sources for the Internet-sociolect are mainly abbreviation, English borrowings into other languages, transfer of meaning, homonymy, broadening or narrowing of meaning, shortened records in numbers and affixation. Neologisms are the prominent feature of the Internet-sociolect in all the languages in the focus of the research. The main objective of the paper consists in investigating the common and distinctive features of the Internet-language in the aspect of the mechanism of the production and functioning of the neologisms. The results of the carried-out research have proved that there exist common strategies and techniques in production of neologisms and that there is a tendency in borrowing English Internet-neologisms into Chinese with different degrees of their adaptation. The urgency of this paper arises from the need for all-sided review of IT language in contemporary linguistic studies. The object of the work are Internet-neologisms viewed as a specific lexical group. The subject are the peculiarities of both the production and loan of Internet-neologisms. The research was conducted on the basis of the English and Chinese languages. The methodology of this research involved the inductive and deductive methods and the method of contrastive analysis. In the course of the research it has been concluded and experimentally and statistically proved that there exist common strategies and tactics of presenting Internet-neologisms in the contrasted languages. It has also been postulated that the pragmatic and the expressive potential of the borrowed English Internet-neologisms is preserved in Chinese. The perspective is seen in reviewing the peculiarities of Internet-language in various Western and Oriental languages.

Key words: Internet-language, Internet-sociolect, English, Chinese, strategies, techniques, neologisms, common and distinctive features.

Ця стаття присвячена проблемі вивчення специфіки мови Інтернету в типологічно неблизько споріднених мовах, що зіставляються: англійській і китайській. На основі аналізу сленгових слів та неологізмів, відібраних із досліджуваних інтернет-чатів (інтернет-жаргонні глосарії) китайською й англійською мовами, зроблено висновок, що джерелами для інтернет-соціолекта $є$ переважно абревіація, англійські запозичення іншими мовами, передача зміста, омонімія, розширення чи звуження значень, скорочені записи в цифрах і афіксація. Неологізми $€$ характерною особливістю інтернет-соціолекту в досліджуваних мовах. Головна мета цієї статті полягає в дослідженні спільних і відмінних рис мови Інтернету в аспекті механізму творення та функціонування неологізмів. Результати здійсненого дослідження підтвердили наявність спільних стратегій і тактик у творенні неологізмів і тенденцію запозичення англійських інтернет-неологізмів китайською мовою з різним ступенем їх адаптації. Актуальність цієї статті зумовлена потребою всебічного огляду мови інформаційних технологій у сучасних лінгвістичних студіях. Об'єктом дослідження є інтернет-неологізми, що розглядаються як специфрічна лексична група. Предметом $€$ особливості творення та запозичення інтернет-неологізмів. Дослідження провадилось на матеріалі англійської та китайської мов. Методологія дослідження охоплює методи індуктивного, дедуктивного, зіставного аналізу. У процесі дослідження зроблено експериментально і статистично підтверджений висновок про наявність спільних стратегій і тактик реалізації інтернет-неологізмів у мовах, що зіставляються. Також установлено, що в китайській мові зберігається прагматичний і експресивний потенціал запозичених англійських інтернет-неологізмів. Перспектива вбачається в огляді особливостей мови Інтернету в різних західних і східних мовах.

Ключові слова: мова Інтернету, соціолект Інтернету, англійська, китайська, стратегії, тактики, неологізми, спільні та відмінні риси. 
Problem-setting and recent papers survey. The objective of the following research is the comparative analysis of the English and Chinese Internet-language. The theoretical grounding for the ideas supplied was formed on the basis of the fundamental scientific works by D. Kerremans, A. Morente, G. Rumŝien', Tugiyanto, Chun ye Zhang, Feiu, Wenying Zhang, Ying nian Tao, Marcin Lewandowski, all of which were dedicated to the study of Internet-language in different languages both in synchrony and diachrony.

The urgency of the topicality is proved by the vast number of publications on the developing Internetlanguage both in the Western and Oriental languages. This research was conducted in the realm of cross-cultural studies. The issues of the interrelation and influence of Internet slang upon the conventional literary language in the contrasted languages both in the lexical and grammatical aspects were elaborated in the scientific publications by such outstanding linguists as A. Artemov, I. Korunets, S. Avrutin, E. Blom, D. Crystal, Ch.N. van Dijk, M. van Witteloostuijn, M. Borovenko, N. Hlazacheva, Chun ye Zhang, Feiu, Wenying Zhang etc. Moreover, there has been also established a universal classification of Internet-neologisms varieties.

On the basis of the analysis of the corpus of slang words and neologisms selected from the investigated Internet-chats (Internet slang glossaries) in Chinese and English there has been concluded that the sources for the Internet-sociolect are mainly abbreviation, English borrowings into other languages, transfer of meaning, homonymy, broadening or narrowing of meaning, shortened records in numbers and affixation. Neologisms are the prominent feature of the Internet-sociolect in all the languages in the focus of the research.

It should be remarked, however, that according to Anglo-Saxon sociolinguistic thought, to which we adhere in this work, the term sociolect is often used interchangeablywithsocial dialect.P.Trudgilldefines it concisely as "a variety or lect which is thought of as being related to its speakers' social background rather geographical background" [1, p. 122]. In other words, it is the language spoken by a particular social group, class or subculture, whose determinants include such parameters as: gender, age, occupation, and possibly a few others. So in this respect Internet-sociolect is understood as a peculiar language functionally specific for on-line chatting and surfing and preserving its distinctive features in different Indo-European languages, both Western and Oriental.

In the table given below there are given all the types of the neologisms most vividly illustrating Internet-sociolect or Internet-language in the contrasted languages (Chinese and English).
The Types of the Internet-Neologisms

\begin{tabular}{|c|c|c|}
\hline \multirow{2}{*}{$\begin{array}{c}\text { The Type of } \\
\text { Neologisms }\end{array}$} & \multicolumn{2}{|c|}{$\begin{array}{c}\text { The Occurrence } \\
\text { in the Contrasted } \\
\text { Languages, \% }\end{array}$} \\
\cline { 2 - 3 } & Chinese & English \\
\hline $\begin{array}{c}\text { Phraseological } \\
\text { units }\end{array}$ & 15 & 30 \\
\hline $\begin{array}{c}\text { Metaphorical } \\
\text { terms }\end{array}$ & 18 & 25 \\
\hline $\begin{array}{c}\text { English } \\
\text { borrowings }\end{array}$ & 25 & - \\
\hline Homonyms & - & 10 \\
\hline Abbreviations & 18 & 10 \\
\hline Graphons & 24 & 10 \\
\hline $\begin{array}{c}\text { Occasional } \\
\text { words }\end{array}$ & & \\
\hline
\end{tabular}

Occasional words functioning as neologisms in Chinese Internet-language are mostly coined by means of affixation. New lexical units are formed by abbreviation to the first letters of the phonetic transcription pin yin presented in Latin in the written form. E.g.: GCD (gòng chăn dăng), CPC (Ukr.: KPK). Other type of formation is composition of several hieroglyphs which is also wide-spread in Chinese. E.g.: The word "Internet" is written in Chinese as "Yīntèwăng" or 因特网.

It should be noted that the Chinese language is rich in homophones, which makes it easy to turn numbers into proxies for words and phrases, like " 88 " ("bābā") or "bye-bye". That explains why "666" ("liùliùliù") refers to the Chinese word for "smooth" or "skilled" (溜, "liù") instead of "the devil".

The Top-10 Internet-neologisms in English according to their frequency and percentage of borrowing into other Indo-European languages are: "avatar", "hashtag", "blog", "trolling", "memes", "spam", "LOL", "meh", "cupertinos" (T9 errors), "geek". These words are very productive and served as a basis for many derivatives like "blogosphere", "spam-free" etc. Among the recently added words to the Online Oxford English Dictionary there such nonce-words as "mwahahaha", "photobombing".

It should be mentioned that among the wordbuilding types in the Internet slanguage also known as the digital jargon there are sound imitation (e.g. "mwahahaha", "meh"), transfer of meaning (e.g. "trolling", "geek", "at" (@)), shortening (e.g. "app" (from "application"), "net" (from "Internet"), compounding (e.g. "upload", "download", "log-in", "homepage", "website", "flashdrive", "smartphone", "hashtag"), acronyms (e.g. "WWW", "GPS", "OMG", "LOL", "PC", "DVD", "CD", "URL”, "USB”); blends (e.g. "mal- 
ware" (from "malicious software") and "blog" ("weblog"); the use of trade names and products such as "Google", "Skype", "iPod" and "iPhone".

In Chinese all the neologisms of English origin are presented as combinations of two or more characters: e.g. "geek” is “极客”, “avatar” is “阿凡 达”, “blog” is “博客”, “hashtag” is “井号”, “spam” is “垃圾邮件”, “trolling” though is presented by one character “电”, “memes” is “模因”, “LOL” is “大声笑”, “cupertinos" is preserved in its original form "cupertinos". Such abbreviations as "WWW", "GPS", "OMG", "LOL", "PC", "DVD", "CD", “URL”, “USB” are presented as “万维网”, “全球定 位系统”, “大声笑”, “个人计算机”, “光盘”, “网址”, while "DVD" and "USB" are preserved in its initial form. "Malware" is also presented by the combination of characters as “恶意软件”, “blog” as “博客”. Unlike Chinese, in Ukrainian Internet-neologisms borrowed from English are functioning in their initial graphic form.
According to the Must-Know Chinese Internet Slang of 2018 the following common Chinese literary expressions have been labeled as "netizens", another Internet-neologism, used to denote words and wordcombinations typical for Internet slanguage. The character 油㖑 (yóuni), formerly used in the meaning of "greasy", came to be interpreted as the elderly ones putting down younger people or being sleazy. The Chinese character gà 㚭 is best known as the second half of the common Chinese word gāngà 尴尤, meaning "awkward". But gradually it acquired the meaning of "small talk". Moreover, there also appeared such words as "gàwǔ" (“价舞”) for “awkward dancing” and "gàchàng” (“伦唱”) for “awkward singing" [4].

It has been concluded that the pragmatic and the expressive potential of the borrowed English Internet-neologisms is preserved in Chinese. The perspective of further research is seen in reviewing the peculiarities of Internet-language in various Western and Oriental languages.

\title{
REFERENCES:
}

1. Trudgill Peter (2003). A Glossary of Sociolinguistics. Oxford University Press.

2. Martseva T. Neologisms in American Electronic Mass Media. Linguistic and Cultural Studies: Traditions and Innovations : Proceedings of the XVII International Conference on Linguistic and Cultural Studies, Russia, Tomsk, 11-13 October, 2017. URL: https://books.google.com.ua/books?id=ink2DwAAQBAJ\&dq=Martseva+ T.A.\& hl =ru\& source = gbs_navlinks_s (last accessed: 05.09.2019).

3. Rumšienè Goda Neologisms of Internet English: Sociolinguistic Aspects of Development, Lithuania, Vilniaus universitetas, 2006. URL: https://wenku.baidu.com/view/98ca486825c52cc58bd 6bebc.html (last accessed: 05.09.2019).

4. The Must-Know Chinese Internet Slang of 2018. URL: https://www.zizzle.io/blog/the-must-know-chineseinternet-slang-of-2018 (last accessed: 05.09.2019).

\section{ЛЕКСИКО-СЕМАНТИЧНІ ВАРІАНТИ ДЛЯ ЛЕКСЕМИ «ПЕДАГОГІКА» В УКРАЇНСЬКІЙ, АНГЛІЙСЬКІЙ ТА ІТАЛІЙСЬКІЙ МОВАХ}

\author{
LEXICO-SEMANTIC VARIANTS FOR A LEXEME "PEDAGOGY" \\ IN THE UKRAINIAN, ENGLISH AND ITALIAN LANGUAGES
}

\author{
Сорочинська I.P. \\ orchid.org/0000-0001-9116-6994 \\ аспірант кафедри прикладної лінгвістики, порівняльного мовознавства та перекладу \\ факультету іноземної філології \\ Національного педагогічного університету імені М.П. Драгоманова
}

